\title{
Early indications of drought impacts on forests in the southeastern United States
}

\author{
by Michael K. Crosby, ${ }^{1, *}$, Zhaofei Fan ${ }^{2}$, Martin A. Spetich ${ }^{3}$, Theodor D. Leininger ${ }^{4}$ and Xingang Fan ${ }^{5}$
}

\begin{abstract}
In the southeastern United States, drought can pose a significant threat to forests by reducing the amount of available water, thereby stressing trees. Destructive changes in crown conditions provide the first visible indication of a problem in a forested area, making it a useful indicator for problems within an ecosystem. Forest Health and Monitoring (FHM) and Palmer's Drought Severity Index (PDSI) data from 11 states in the southeastern United States were obtained in an effort to determine the role that drought, forest type, and ecoregion have in indicating differences in crown dieback. Analyses were conducted by species groups using classification and regression tree (CART) analysis. The greatest amount of total relative crown dieback occurred in red oak (18\%), followed by other hardwoods (14\%), and white oak (11\%). Relative crown dieback varied by forest type and ecoregion with a relationship to drought in both red oak and white oak. This information will be useful for focusing future research and modeling efforts to predict forest health conditions affected by changing climate variables.
\end{abstract}

Keywords: Crown dieback, Forest health, Drought, CART

\section{RESUMÉ}

Dans le sud-est des États-Unis, la sécheresse peut représenter une menace sérieuse pour les forêts en réduisant la quantité d'eau disponible, et en conséquence provoquer un stress chez les arbres. Des changements destructifs au niveau des cimes constituent la première indication visible d'un problème dans les régions boisées, devenant de ce fait un précieux indicateur des problèmes affectant un écosystème. Les données tirées de lindice de santé et de suivi des forêts (FHM) et de lindice de sévérité de sécheresse de Palmer (PDSI) de onze états du sud-est des États-Unis ont été colligées dans le but de déterminer le rôle joué par la sécheresse, par le type de forêt et par lécorégion au niveau des différences rattachées au dépérissement des cimes. Les analyses ont été menées par groupes d’espèces au moyen d'une analyse des arbres de classification et de régression (CART). Le plus fort niveau de dépérissement relatif total des cimes a été retrouvé chez le chêne rouge (18\%), suivi des autres feuillus (14\%) et du chêne blanc (11\%). Le dépérissement relatif des cimes variait selon le type de forêt et lécorégion et en fonction de la sécheresse affectant le chêne rouge et le chêne blanc. Cette information permettra de concentrer les efforts futurs de recherche et de modélisation visant à prédire les conditions de santé des forêts affectées par des changements climatiques.

Mots clés : Dépérissement de la cime, santé des forêts, sécheresse, CART

\section{Introduction}

Concerns over global climate change and the potential impacts on forests in the United States have increased in recent years. This is particularly true for southeastern forests which encompass approximately 81 million hectares, some $27 \%$ of the total forest cover in the US. Southern forests also account for more than $60 \%$ of total removals of growing stock timber-approximately 283 million cubic metres $\left(\mathrm{m}^{3}\right)$ in 2006 (Smith et al. 2009). Damage to forests can occur from a variety of weather events, such as severe wind (e.g., tornadoes and hurricanes), droughts, and ice storms. This damage can increase fuel for wildfires (Cooke et al. 2007), release carbon dioxide $\left(\mathrm{CO}_{2}\right)$ into the atmosphere, and reduce the amount of $\mathrm{CO}_{2}$ that can be sequestered in forests (Crosby et al. 2008). It has been suggested that severe weather events could occur more frequently under changing climate conditions; climatic fluctuations could also have long-term implications for southern forests regarding species composition and ranges, severe weather events, and prolonged periods of drought (Field et al. 2007).

A drought is a period of time with rainfall deficiencies and often elevated temperatures, which can last from a few months to years, but can take on multiple definitions (Palmer 1965, Wilhite 2000). This marked decrease in precipitation reduces the amount of water available to trees and leads to stress for growing biomass (Barnes et al. 1998). The continual stress on trees from a lack of available soil moisture results in death of parts of the root system that is subsequently expressed in the crown, and if conditions persist or become more severe, proceed downward to the trunk possibly result-

\footnotetext{
${ }^{1}$ Shorter University-Department of Natural Science, 315 Shorter Avenue, Rome, GA 30165 USA

*Corresponding author's email: mcrosby@shorter.edu

${ }^{2}$ Auburn University-School of Forestry and Wildlife Sciences, SFWS 3219602 Duncan Dr. Auburn, AL 36849 USA

${ }^{3}$ Arkansas Forestry Sciences Laboratory, U.S. Forest Service, Southern Research Station, P.O. Box 1270, Hot Springs, Arkansas 71902 USA ${ }^{4}$ USDA Forest Service, Center for Bottomland Hardwoods Research, P.O. Box 227432 Stoneville Road, Stoneville, MS $38776-0227$ USA

${ }^{5}$ Western Kentucky University, Department of Geography and Geology, 1906 College Heights Blvd., \#31066 Bowling Green, KY 42101 1066 USA
} 


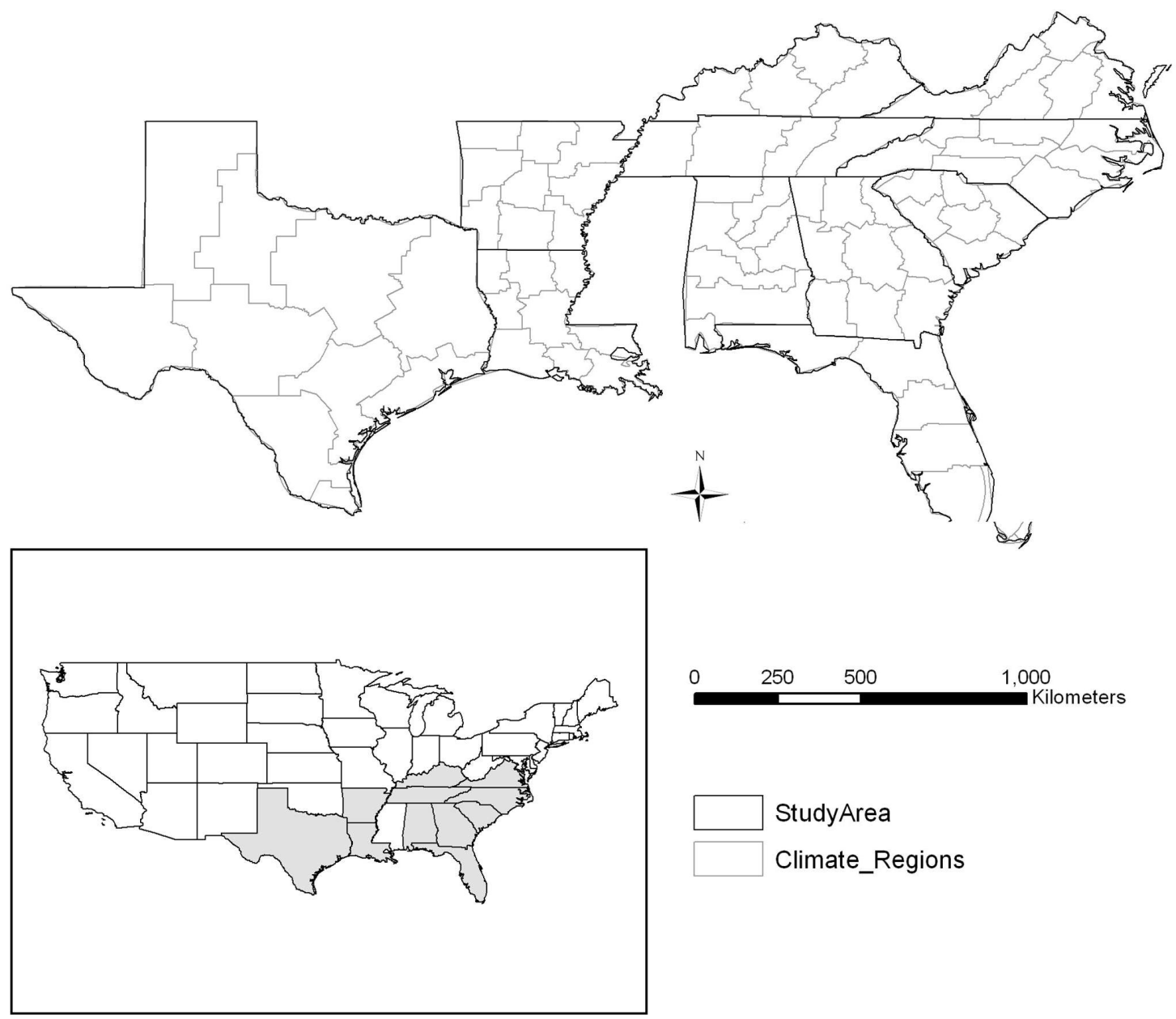

Fig. 1. Study area in southeastern United States from which PDSI data were obtained.

ing in mortality (Millers et al. 1989, Barnes et al. 1998). Even in those trees that do not immediately succumb to drought, there is a marked decrease in the amount of foliage (increased dieback), that leads to an increased likelihood of mortality (Suarez et al. 2004). An immediate threat of prolonged drought is a decrease in annual growth (Voelker et al. 2008, Klos et al. 2009), which over time reduces the amount of available biomass for harvest. If droughts persist, or become more severe, mortality rates increase (Klos et al. 2009) which can have implications for insect infestations or provide fuel for a catastrophic wildfire (Cooke et al. 2007, Williams et al. 2010).

A commonly used method of assessing drought is via the Palmer Drought Severity Index (PDSI). This provides a comparison of current precipitation levels in a certain period of time for some area, compared to what is considered climatologically "normal" (Palmer 1965). This index has been commonly used by various researchers to define drought in the US (Dai 2011). It has also been combined with forest inventory variables (e.g., basal area, height, age) in an attempt to model the impact of drought on growth and mortality of US forests (Klos et al. 2009, Fan et al. 2012)

Crown health indicators, specifically crown dieback, designated by the United States Department of Agriculture
(USDA) Forest Service can be utilized to indicate tree stress. Crown dieback signifies the amount of actual crown death that has occurred in a tree (Schomaker et al. 2007). This measurement has been used as an indicator of tree health (Hogg et al. 2008), with those trees having greater than $20 \%$ dieback being classified as unhealthy (Alexander and Palmer 1999). Lee et al. (2014) found that increased levels of crown dieback were related to an increased likelihood for mortality in two oak species in Missouri.

Efforts have also been made to link crown dieback with climate events (e.g., La Niña). For example, a relationship was indicated between dieback and snow depth in northern hardwood species (Auclair and Heilman 2003). Randolph et al. (2009) found that northern white-cedar (Thuja occidentalis L.) showed greater amounts of crown dieback than other species in a study in Michigan and Maine, concluding changes in dieback may be species specific. Analyzing patterns of crown dieback across the US utilizing FHM data, confirms that there are differences in dieback at least at the species group level (e.g., pine, oak, maple) based on data collected through 2004 (Randolph 2009). For example, maple (Acer spp.) species show elevated dieback throughout the northeastern US, while red oaks show elevated dieback in the Ozarks; in the western US, indications are that oaks show greater 
dieback (Randolph 2009). Some of this dieback may be attributed to additional stress from diseases and/or insect infestation (Fan et al. 2008). In the southeastern US, it has been shown that crown dieback occurs more frequently in hardwood than in pine forests (Randolph 2009), specifically those dominated by red oak (Randolph et al. 2009).

Monitoring forest susceptibility to damage over a large spatial scale is imperative if there is to be an understanding of the interaction between climatic factors and forests. With this in mind, we attempted to determine the relationship between relative crown dieback and forest types, ecoregions (Bailey 1983), and drought for the southeastern US. Based on previous exploratory work (Crosby et al. 2012), our objective was to stratify plot-level inventory data into three groups (i.e., red oaks, white oaks, and other hardwoods) which allowed us to develop non-parametric classification and regression tree (CART) models to tentatively determine variations in crown dieback levels of selected species relating to forest type, ecoregion (Bailey 1983), and historical drought. Our hypothesis is that crown dieback in these three species groups will vary within different forest types and ecoregions and vary as the amount of drought varies across the southeastern United States. This analysis could provide guidance regarding the potential future impacts of drought on southeastern forests as well as allow researchers to determine areas for further study relating climatic variables to forest health.

\section{Materials and Methods Study Area}

The study area encompasses 11 states in the southeastern United States-Alabama, Arkansas, Florida, Georgia, Kentucky, Louisiana, North Carolina, South Carolina, Tennessee, Texas, and Virginia (Fig. 1). Mississippi and Oklahoma were excluded because of a lack of data necessary for the analysis. With the exception of extreme southeastern portions of Florida and a few areas at higher elevations in the Appalachian Mountains, the vast majority of the area experiences a humid subtropical climate with warm, humid summers and mild to cool winters. Within this region, however, temperature and precipitation can vary significantly with average annual temperatures ranging between $10^{\circ} \mathrm{C}$ and $23.9^{\circ} \mathrm{C}$ and precipitation between approximately 650 and $2000 \mathrm{~mm}$ (Arguez et al. 2012). Forest types found in the southeastern United States include longleaf-slash pine, loblolly-shortleaf pine, oak-pine, and oak-hickory (http:// www.fia.fs.fed.us/library/maps/docs/forestcover.pdf).

\section{Data}

Crown dieback data were obtained from the USDA Forest Service, Forest Inventory and Analysis (FIA) program and Forest Health Monitoring (FHM) data (available at: http://apps.fs.fed.us/fiadb-downloads/datamart.html; for details on sampling design, see Bechtold and Patterson 2005). Queries were designed for each state to extract FHM data (i.e., for crown dieback) from 2003-2010. Crown dieback (expressed as a percentage), plot location (latitude and longitude), and inventory year were extracted for each record used in the study. Relative crown dieback was then calculated in an effort to remove any variation in crown dieback related to averaging for all species on a plot. Average crown dieback for each species group was calculated as:
1) $\bar{X}_{i}=\frac{1}{m} \sum_{j=1}^{m} X_{i, j}$

Where $x_{i, j}$ is the crown dieback data for the group $i$ (i.e., red oak, white oak, or other hardwoods); $m$ is the number of samples (trees) in the group. Relative Crown Dieback (RCD) for each group was then calculated by:

2) $R C D_{i}=\frac{\bar{X}_{i}}{\sum_{i=1}^{n} \bar{X}_{i}}$

Where $\mathrm{n}$ is the number of species groups.

Data were then stratified by species group using FIA codes queried from the database (e.g., pine group, red oak group, white oak group, and other hardwoods group) to allow for a region-wide assessment of drought impacts on forest health via CART modeling (Steinberg and Colla 1997, Death and Fabricius 2000). The species groups addressed in this study are based upon previous exploratory work (Crosby et al. 2012, Fan et al. 2012) and allow for analysis of various oak species groups which are the dominant hardwood species in the eastern United States.

PDSI data were obtained from the National Climate Data Center (NCDC) by climate division (Fig. 1) for each state in the study (http://www7.ncdc.noaa.gov/CDO/CDODivisionalSelect.jsp). These data were calculated based on the methodology of Palmer (1965) and were obtained as monthly averages. These were then averaged annually for the years 1994-2010 and plotted to show the onset and duration of growing-season (i.e., March-September) drought events throughout the southeastern US.

\section{Analysis}

CART analysis is a non-parametric method that is utilized to explain the response in the variation of one variable (i.e., crown dieback) in relation to one or more explanatory variables (Death and Fabricius 2000). Analysis begins with the whole dataset (i.e., root node) which is then partitioned based on all possible splitting criteria, which are based upon the homogeneity of the subsequent splits (i.e., child nodes) (Steinberg and Colla 1997). The splitting process continues until there are no more possible splits, known as terminal nodes (Lewis 2000). After the initial fitting, over-fit trees are produced. The initial trees were then pruned using the costcomplexity parameter (Steinberg and Colla 1997) which measures the accuracy added by a split to the regression (or classification) tree. Nodes are pruned away as the cost-complexity parameter increases, revealing a simpler tree which captures significant relationships between the response variable (here, the relative crown dieback) and a set of factors of interest. CART analysis was performed using the "rpart" package (Therneau et al. 2012) via $\mathrm{R}$ statistical software (R Core Development Team 2012).

The PDSI data were summarized to illustrate the cumulative effect on crown dieback, as the duration and severity of drought events are captured through this cumulative measure. This allowed crown dieback to be included in CART models to determine any immediate or cumulative effect 


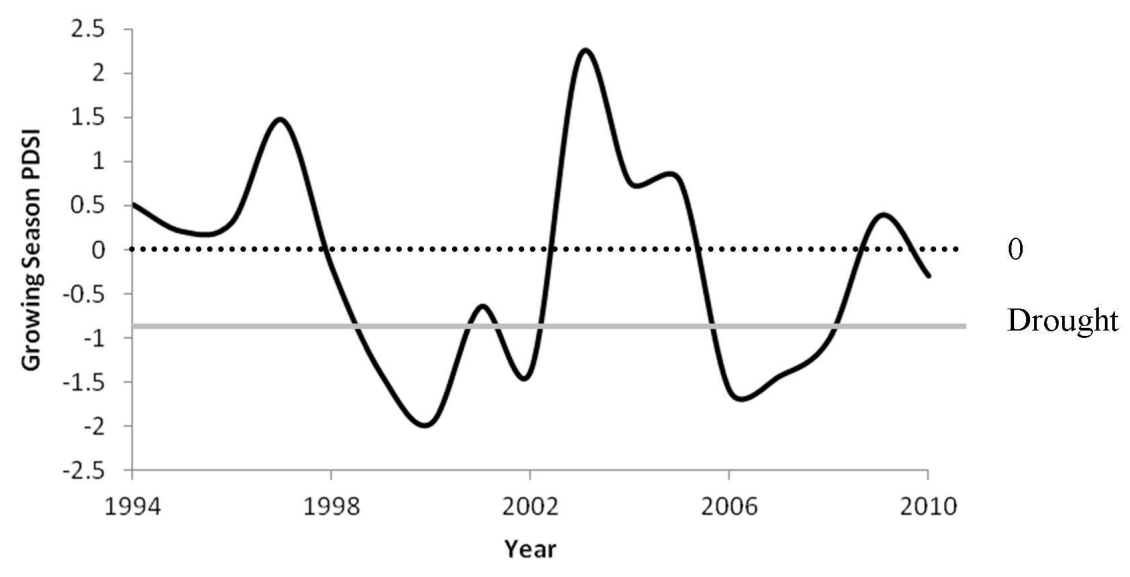

Fig. 2. Growing season (March-September) PDSI for the southeastern United States (drought conditions are those found below the line labeled drought].

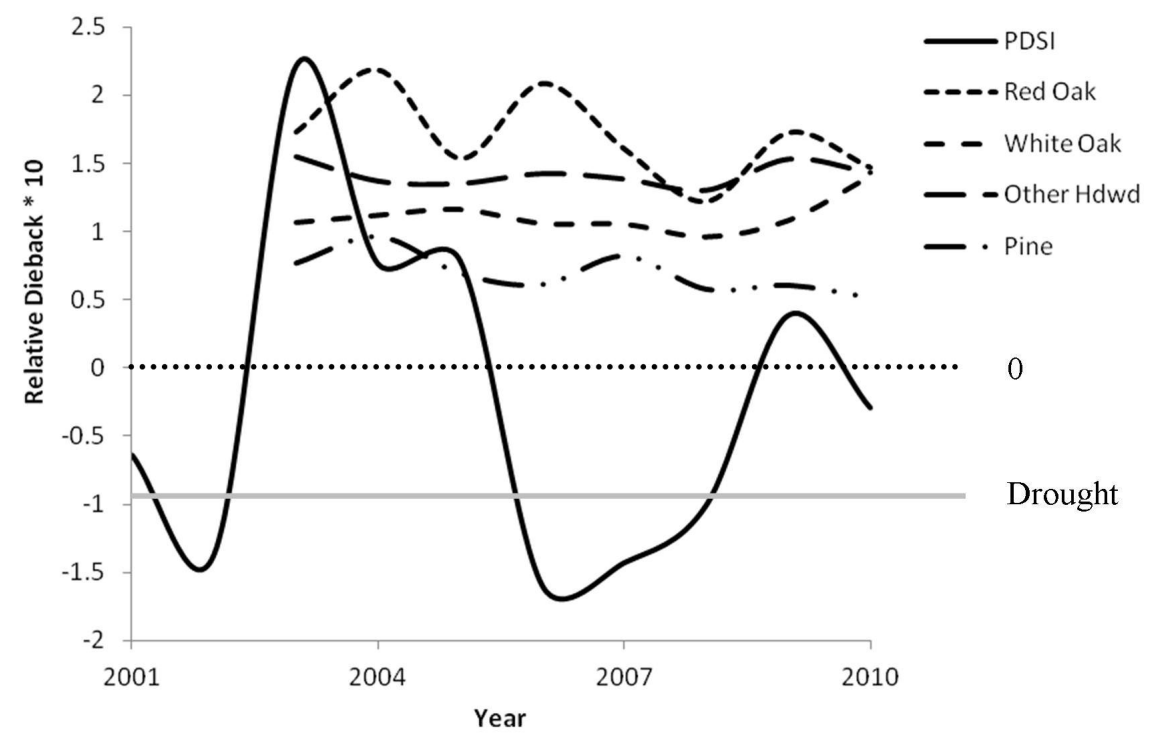

Fig. 3. Relationship between relative crown dieback (here multiplied by 10 ) for each species group and PDSI (drought conditions are those found below the line labeled drought].

with the onset of drought, by species group. PDSI values were extracted for each FHM plot location, using ArcGIS software, allowing for a complete dataset of crown dieback and PDSI for each tree record in the dataset. The data were then extracted by plot location within each forest type/group and ecoregion, making it possible to perform CART analyses to determine the changes in relative crown dieback differences between forest types/groups, ecoregions, and varying degrees of drought. The goal of our CART analysis is to separate crown dieback into homogeneous groups relating to the three variables so that we can identify the forest type and/or ecoregion at risk. The nodes (splits) to the right indicate an increased percentage of crown dieback, with splits to the left showing a lesser amount of crown dieback.

\section{Results}

Red oak had the greatest level of relative crown dieback of the three groups, approximately $18 \%$ dieback for all samples; white oak and other hardwoods exhibited $11 \%$ and $14 \%$ crown dieback, respectively. Two distinct periods (1999-2002 and 2006-2008) of region-wide drought (i.e., PDSI values $<-0.99$ ) were detected across the southeastern US, using the PDSI values (Fig. 2). The 2006-2008 drought was over by 2009 , with 2010 indicating a return to dry conditions (i.e., PDSI values between -0.5 and -0.99 ). The relationship between drought and the impacts on crown dieback can be seen, generally, within two years of the onset of drought (Fig. 3). 


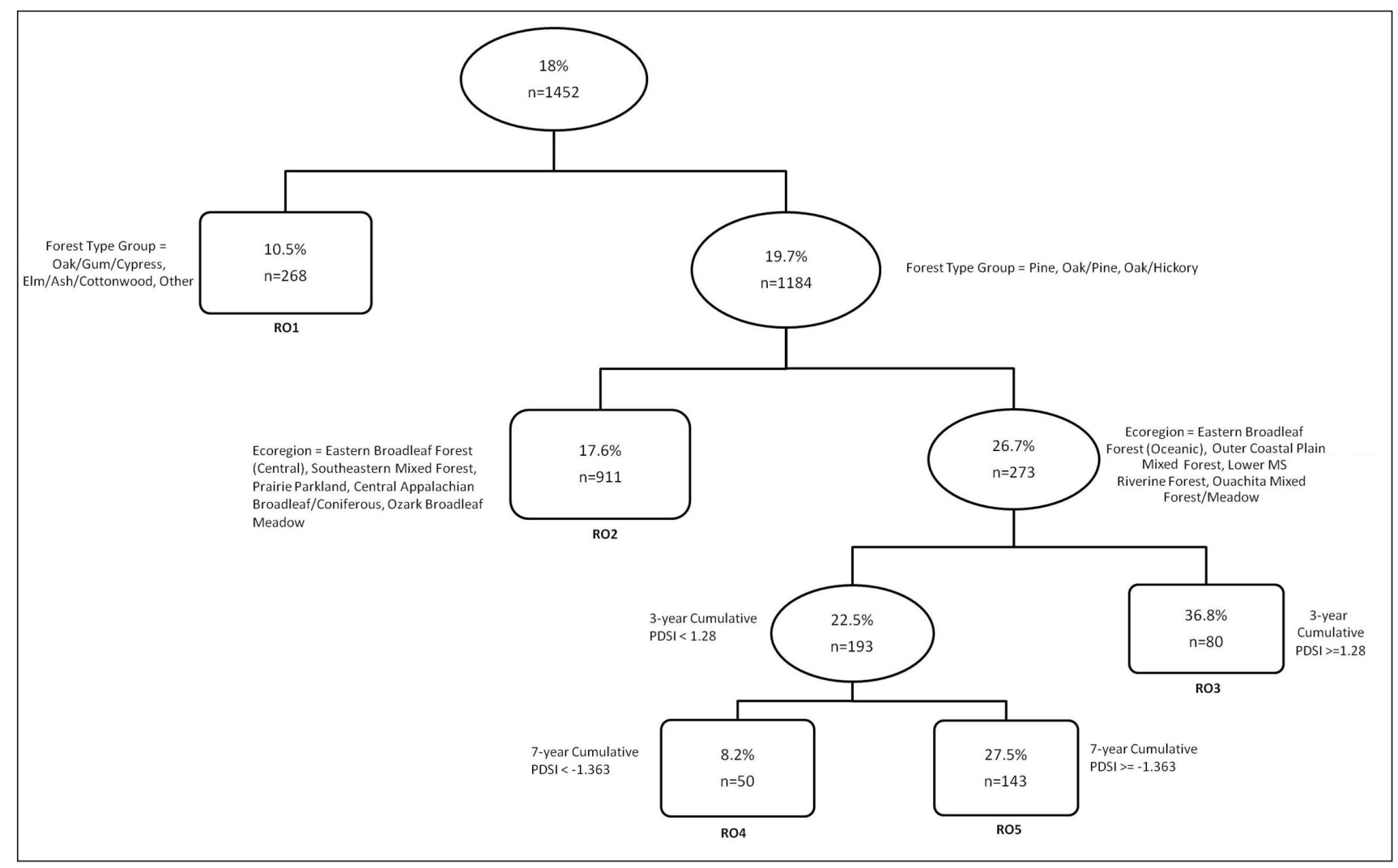

Fig. 4. CART model for relative crown dieback for the red oak species group. Statistically significant splits are shown with relative crown dieback expressed as a percentage and the number of plots ( $\mathrm{n}$ ) of each node. Nodes are numbered (ex. R01 is the first terminal node for the red oak species group].

The pruned CART results for red oak, white oak, and other hardwoods had five, five, and two terminal nodes, respectively (Figs. 4-6; the pine species group produced no significant CART model and is therefore not presented here). For red oak (Fig. 4) and other hardwoods (Fig. 6), forest type was the most significant factor relating to crown dieback. The relative amount of crown dieback in the first split for red oak was approximately $20 \%$ in the pine, oakpine, and oak-hickory forest groups and $10.5 \%$ in the oakgum-cypress and elm-ash-cottonwood groups. Within the red oak group, following the division by forest type, ecoregion is where the next split occurs. The greatest value, $26.7 \%$, of crown dieback was found within the Eastern Broadleaf, Outer Coastal Plain, Lower Mississippi Riverine, and Ouachita Mixed Forest ecoregions. Three-year and seven-year cumulative PDSI values become important factors beyond the division by ecoregion (Fig. 4; nodes $\mathrm{RO} 3$ and RO5). The greatest crown dieback for red oak occurs with a three-year cumulative PDSI value greater than 1.28. Species in the other hardwoods group had $42.6 \%$ crown dieback related to pine and oak-pine forest types. The other hardwoods group had no significant division beyond forest types.

For white oak (Fig. 5), ecoregion proved to be the most significant factor. The greatest crown dieback for white oak in the first split occurred in the Prairie Parkland ecoregion, with approximately $33 \%$ crown dieback. The greatest level of crown dieback occurred in white oak with a seven-year cumulative PDSI value in pine, oak-hickory, and oak-gum- cypress forest types with approximately $65 \%$ crown dieback (Fig. 5; node WO5); however, it must be noted that there were only 13 plots that met these criteria.

\section{Discussion}

The CART models for each species group reflect the difference in the amount of crown dieback that occurs as a function of drought severity within different forest type and ecoregions. These differences can provide insight into the relationship between drought and crown dieback and may provide forest managers with an early detection tool that allows for the mitigation of increased levels of mortality and/or subsequent problems from insect infestation or forest fires (Williams et al. 2010). The three species groups that produced a regression tree (i.e., red oaks, white oaks, other hardwoods) exhibit varying levels of relative crown dieback. This trend follows similar patterns of decline found in other studies that suggest varying degrees of drought impact on forest types/species and a temporal lag between the onset of drought conditions and the effects on forests (Oak et al. 1996, Spetich and He 2008, Fan et al. 2011) to that found with relative crown dieback (Fig. 3).

Since red and white oaks are the dominant hardwood species in the eastern US, it is important to monitor the risks posed to these forests where they occur. Some similarities exist between the three models with regard to the forest types in which the greatest relative crown dieback levels occur. The three groups analyzed share a similar characteristic with 


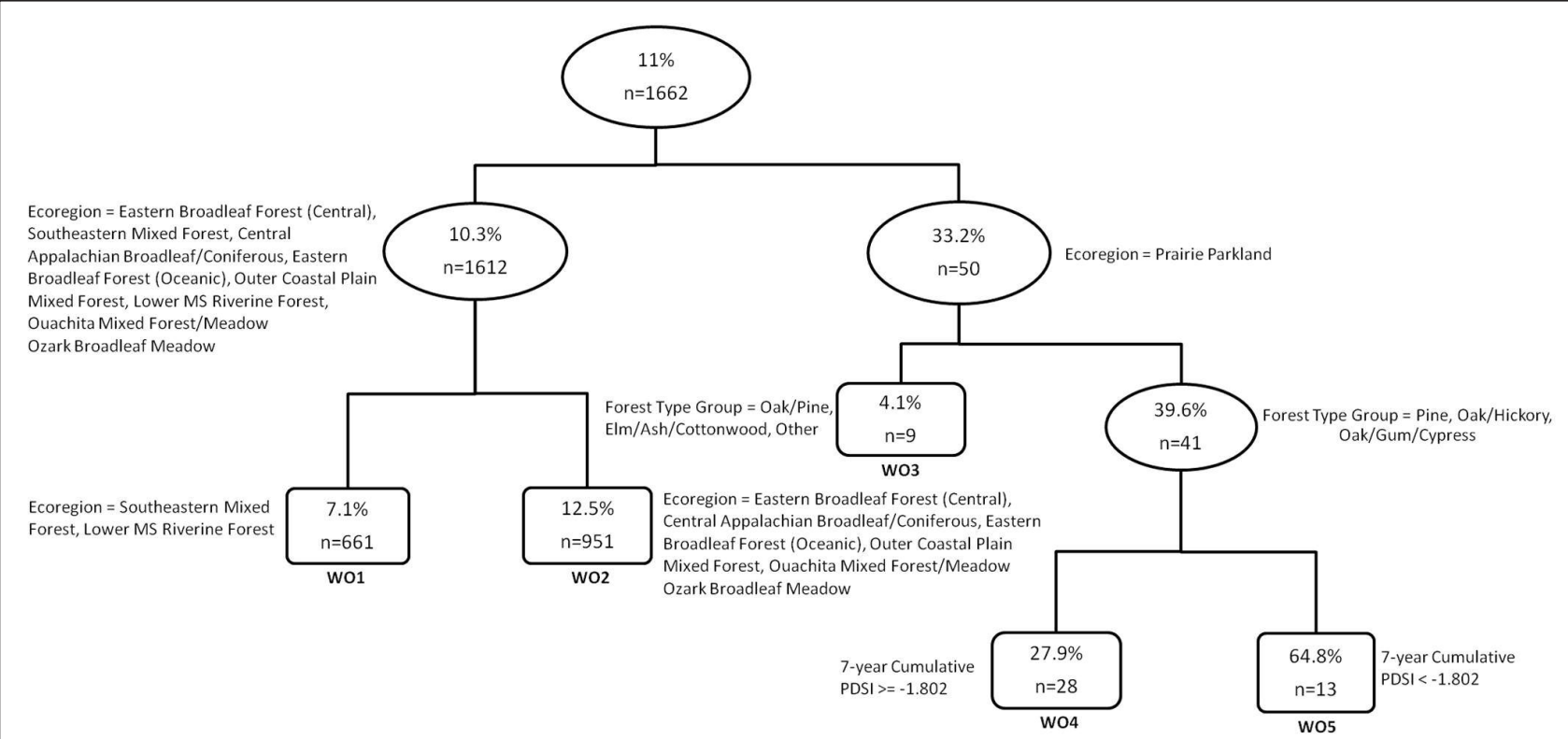

Fig. 5. CART model for relative crown dieback for the other hardwoods species group. Statistically significant splits are shown with relative crown dieback expressed as a percentage and the number of plots ( $\mathrm{n}$ ) of each node. Nodes are numbered (ex. OH1 is the first terminal node for the other hardwoods species group).

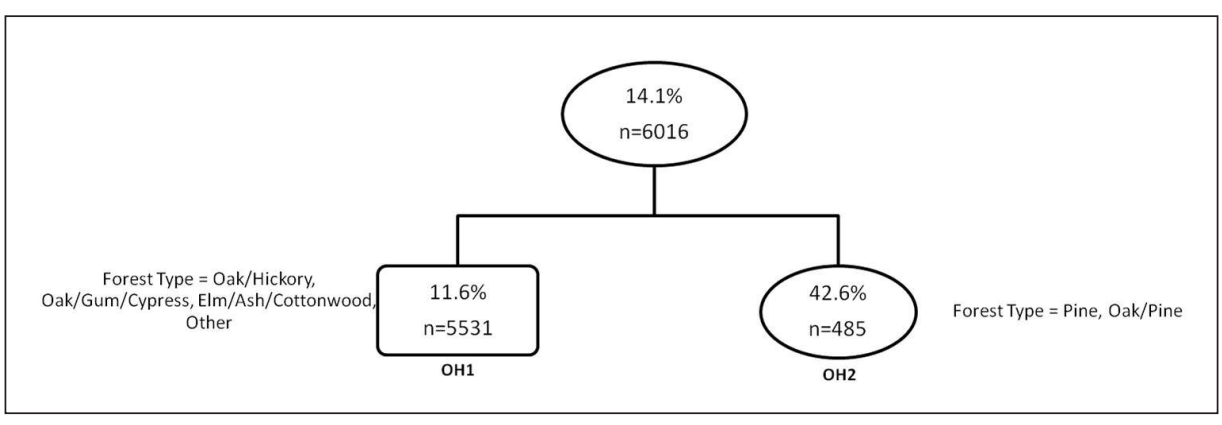

Fig. 6. CART model for relative crown dieback for the white oak species group. Statistically significant splits are shown with relative crown dieback expressed as a percentage and the number of plots (n) of each node. Nodes are numbered lex. W01 is the first terminal node for the white oak species group).

splitting in the CART models as all are associated with the pine forest type, and the red oak and other hardwoods species are also associated with the oak-pine forest type. Pine species typically have less leaf area compared to other species and are more resilient to drought while many hardwood species shed leaves as a reaction to drought stress (Barnes et al. 1998, Chakraborty et al. 2013). Zwieniecki et al. (2004) suggest that leaf shape and area of the northern red oak (Quercus rubra L.) are impacted by the environment. Drought that occurs in the non-growing season or during the early part of the growing season could lead to trees producing smaller leaves as a means to compensate for low water availability. As temperatures continue to increase during the summer, however, the lack of available water would lead to dieback of the tree (Chakraborty et al. 2013) as energy expended for shoot production and maintenance is reduced. The loss of shoot production and a reduction of branching in the crown predispose the trees to mortality (Voelker et al.
2008). It is likely that during periods of intense drought (or recurring/subsequent droughts), hardwood species are out-competed for resources in mixed pine-hardwood stands.

The greatest levels of crown dieback are found (for red oaks and white oaks groups) to be associated with drought conditions (Fig. 4-Fig. 6), although for the white oak species the number of samples is low. The CART models for all species groups show that crown dieback levels are greater in upland forest type groups (e.g., Pine, Oak-Pine, and OakHickory forest types), where a lack of rainfall may be exacerbated by already dry, low fertility soils. The forest types and ecoregions themselves are, roughly, a reflection of past moisture and temperature distribution. Ecoregions include similar soils, physiography, and other natural variables $(\mathrm{McNab}$ and Avers 1994) that could point to local site factors that should be considered. For example, red oak crown dieback is greater in the Outer Coastal Plain Mixed Forest ecoregion than in the Southeastern Mixed Forest ecoregion for upland forest types (e.g., Oak-Pine, Oak-Hickory) which suggests that a finer scale of analysis (e.g., ecoregion section) could further refine models. Future work will consider the hierarchical nature of these groupings.

The greatest relative crown dieback values for red oak follows the split by ecoregions varies. The species reveals an increase in relative crown dieback following periods of drought. The split at node RO3 (Fig. 4) is for three-year 
cumulative PDSI of 1.28 which would indicate a period of drought at some point, given the low cumulative PDSI value. Three-year cumulative PDSI of less than 1.28 and a sevenyear cumulative PDSI of $\geq-1.36$ (Fig. 4; node RO5) indicate that crown dieback increases with prolonged drought or because several short periods of drought-like conditions have occurred over the southeastern U.S. during the past 15 years. Multiple short-term droughts have been shown to increase the likelihood of decline in red oak species (Tainter et al. 1990), although as Oak et al. (1996) and Fan et al. (2006) suggested, stand/site characteristics should also be considered.

While we only consider drought in this study, it is possible that other variables could further explain varying levels of crown dieback. For example, Klos et al. (2009) found that older, denser oak stands exhibited more susceptibility to drought in a study that included Alabama, Georgia, and Virginia. Further, Fan et al. (2006) found that red oak mortality is greater relative to white oak mortality in areas impacted by drought in the Ozark Highlands. The relationship between drought and mortality may be stronger in localized areas (Fan et al. 2012, Crosby et al. 2014); while we show variation between drought and crown dieback by forest types and/or ecoregion, it must be remembered that local site factors (e.g., aspect, soils.) likely play a role in the ultimate impact of drought on crown dieback.

\section{Management Implications}

While this study only addresses the relationship between crown health (via relative crown dieback) and drought and the differences in relative crown dieback at the forest type and ecoregion levels, there are still implications for the management of forested areas in the southeastern United States. If current projections are realized, the southern US could see increased periods of drought and an increase in the duration of drought (Dai 2011) which could have dire implications for forests in the region. The most notable finding here is that crown dieback levels are greater for oak species in pine or mixed-oak forest types and in primarily coastal ecoregions with typically abundant growing-season rainfall. A reduction in competition in areas managed for hardwood production may reduce the loss in crown health with these species groups.

Declines in crown health could lead to secondary impacts from insects (Fan et al. 2008) or may ultimately lead to increased levels of mortality. A subsequent study will assess the relationship between increases in crown dieback and mortality across the same study area that should yield specific recommendations regarding species and stocking levels. The results here are intended to serve as a guide or first approximation of the impacts of drought on forest health in the region.

\section{Conclusions}

This study has shown the differences in crown dieback in the southeastern US as they relate to different forest types, ecoregions and drought. The red oak species group showed the greatest variation in crown health loss at the scales analyzed and were impacted most by drought. White oaks and other hardwoods were impacted to a lesser degree and with less spatial variation (i.e., fewer ecoregions with significance in CART models), indicating that red oaks are more susceptible to drought. Where drought was a factor, it appears that the greatest level of crown dieback occurred following a sustained period of drought. There are likely changes in biotic and abiotic factors that were not analyzed that have an impact on changes in crown health.

Now that initial impacts of drought have been found for species groups within various forest types and ecoregions, further analysis can be refined to identify additional variables that may impact overall forest health. Models to predict climatic and site variables impacting crown health will be developed as a means of identifying areas that could be susceptible to further damage, including: infestation from insects, disease, natural disasters, or fire. This would make it possible to project future impacts of climate change on forests in the southeastern United States. Forest managers could benefit from this information as it could immediately assist them by identifying areas susceptible to damage (e.g., increased fuel load for fires) or by identifying trends in species that may have a tolerance for drought. This knowledge could be used to promote management for the regeneration of species, or the planting of species that allow for more consistent timber growth regardless of drought conditions.

Future research should investigate predictors of crown dieback that eventually lead to mortality; although this would have to be done at the individual tree level, it could provide insight into various species ability to recover from drought. It seems from this research that utilizing PDSI to assess crown health is a good first step towards identifying areas that should be monitored for crown health issues. Even though PDSI alone cannot be used to model crown dieback directly, using additional climate variables to analyze crown conditions at a smaller scale may be possible.

\section{Acknowledgements}

This project was funded through grants from the U.S. Forest Service Forest Health Monitoring Program (\#SO-EMF-10-01) and NASA ROSES program via subcontract (WKU5162201000110070670). The authors would also like to thank two anonymous reviewers for their constructive reviews of this manuscript.

\section{References}

Alexander, S.A. and C.J. Palmer. 1999. Forest health monitoring in the United States: first four years. Environ. Monit. Assess. 55(2): 267-277.

Arguez, A., I. Durre, S. Applequist, R.S. Vose, M.F. Squires, X. Yin, R.R. Heim, and T.W. Owen. 2012. NOAA's 1981-2010 U.S. climate normals: An overview. B. Am. Meteorol. Soc. 93: 1687-1697.

Auclair, A.N.D. and W.E. Heilman. 2003. Predicting forest dieback using global climate indicators: Is it possible? In: Proceedings of the US Forest Health Monitoring Program Workshop, Monterey, CA, January 28-30, 2003. Available at: http://fhm.fs.fed.us/posters/ posters03/dieback.pdf. Last accessed: August 4, 2011.

Bailey, R. G. 1983. Delineation of ecosystem regions. Environ. Manage. 7: 365-373.

Barnes, B.V., D.R. Zak, S.R. Denton and S.H. Spurr. 1998. Forest Ecology. John Wiley \& Sons, New York, NY. 774 pp.

Burns, R.M. and B.H. Honkala. 1990. Silvics of North America: 2. Hardwoods. Agriculture Handbook 654. U.S. Department of Agriculture, Forest Service, Washington, D.C. vol. 1877 pp.

Bechtold, W.A. and P.L. Patterson. 2005. The enhanced Forest Inventory and Analysis program-national sampling design and estimation procedures. Gen. Tech. Rep. SRS-80. Asheville, NC: U.S. Department of Agriculture, Forest Service, Southern Research Station. 85 pp. 
Chakraborty, T., S. Saha, and A. Reif. 2013. Decrease in available soil water storage capacity reduces vitality of young understorey European Beeches (Fagus sylvatica L.) - A case study from the Black Forest, Germany. Plants 2: 676-698.

Cooke, W.H. III, K. Grala, D. Evans and C. Collins. 2007. Assessment of pre- and post-Katrina fuel conditions as a component of fire potential modeling for southern Mississippi. J. Forest. 105(8): 389-397.

Crosby, M.K., T.G. Matney and E.B. Schultz. 2008. Multi-state forest carbon storage estimates: balances, baselines, and catastrophic losses. In: Proceedings of the 2008 Society of American Foresters National Convention, Reno, NV, November 3-9, 2008. [CD-ROM]. Crosby, M.K., Z. Fan, M.A. Spetich, T.D. Leininger and X. Fan. 2012. Relationship between crown dieback and drought in the southeastern United States. pp 316-318. In: Morin, Randall S., Liknes, Greg C. 2012 (eds.). Moving from Status to Trends: Forest Inventory and Analysis (FIA) Symposium 2012; 2012 December 46; Baltimore, MD. Gen. Tech. Rep. NRS-P-105. Newtown Square, PA: U.S. Department of Agriculture, Forest Service, Northern Research Station.[CD-ROM]. 478 pp.

Crosby, M.K., Z. Fan, T.D. Leininger, M.A. Spetich, and A.B. Self. 2014. Spatial trends and factors associated with hardwood mortality in the southeastern United States. Southeastern Geographer 54(1): $72-85$.

Dai, A. 2011. Drought under global warming: a review. Wiley Interdisciplinary Reviews: Climate Change 2(1): 45-65. DOI: 10.1002/ wcc.81.

De'ath, G. and K.E. Fabricius. 2000. Classification and regression trees: A powerful yet simple technique for ecological data analysis. Ecol. 81(11): 3178-3192.

Fan, Z., J.M. Kabrick and S.R. Shifley. 2006. Classification and regression tree based survival analysis in oak-dominated forests of Missouri’s Ozark highlands. Can. J. Forest Res. 36(7): 1760-1748.

Fan, Z., J.M. Kabrick, M.A. Spetich, S.R. Shifley and R.G. Jensen. 2008. Oak mortality associated with crown dieback and oak borer attack in the Ozark Highlands. Forest Ecol. Manage. 255(7): 2297-2305.

Fan, Z., X. Fan, M.A. Spetich, S.R. Shifley, W.K. Moser, R.G. Jensen and J.M. Kabrick. 2011. Developing a stand hazard index for oak decline in upland oak forests of the Ozark Highlands, Missouri. North. J. Appl. For. 28(1): 19-26.

Fan, Z., X. Fan, M.K. Crosby, W.K. Moser, H. He, H., M.A. Spetich and S.R. Shifley. 2012. Spatio-temporal trends of oak decline and mortality under periodic regional drought in the Ozark Highlands of Arkansas and Missouri. Forests 3(3): 614-631. doi: 10.3390/ f3030614.

Field, C.B., L.D. Mortsch, M. Brklacich, D.L. Forbes, P. Kovacs, J.A. Patz, S.W. Running and M.J. Scott. 2007. North America. P. 617-652 In: Climate Change 2007: Impacts, Adaptation and Vulnerability. Contribution of Working Group II to the Fourth Assessment Report of the Intergovernmental Panel on Climate Change, M.L. Parry, O.F. Canziani, J.P. Palutikof, P.J. van der Linden and C.E. Hanson (eds.). Cambridge University Press, Cambridge, UK,

Hogg, E.H., J.P. Brandt, and M. Michaelian. 2008. Impacts of a regional drought on the productivity, dieback, and biomass of western Canadian aspen forests. Can. J. Forest. Res. 38: 1373-1384.

Klos, R.J., G.G. Wang, W.L. Bauerle and J.R. Rieck. 2009. Drought impact on forest growth and mortality in the southeast USA: An analysis using Forest Health and Monitoring data. Ecol. Appl. 19(3): 699-708.

Lee, C.A., S. Voelker, R.M. Holdo, and R.M. Muzika. 2014. Tree architecture as a predictor of growth and mortality after an episode of red oak decline in the Ozark Highlands of Missouri, U.S.A. Can. J. Forest Res. 44: 1005-1012.

Lewis, RJ. 2000. An introduction to classification and regression tree (CART) analysis. Proceedings of the Annual Meeting of the Society for Academic Emergency Medicine, San Francisco, California.
McNab, W.H. and P.E. Avers, P.E. 1994. Ecological subregions of the United States: section descriptions. Administrative Publication WO-WSA-5. Washington, DC: U.S. Department of Agriculture, Forest Service. 267 pp.

Millers, I., D.S. Shriner and D. Rizzo. 1989. History of hardwood decline in the Eastern United States. Gen. Tech. Rep. NE-126. Radnor, PA: U.S. Department of Agriculture, Forest Service, Northeastern Forest Experiment Station. 75 pp.

Oak, S., F. Tainter, J. Williams and D. Starkey. 1996. Oak decline risk rating for the southeastern United States. Ann. Forest Sci. 53 (2-3): 721-730

Palmer, W.C. 1965. Meteorological drought. Research Paper No. 45. U.S. Department of Commerce, 1965, 58 pp.

$\mathrm{R}$ Core Development Team. 2012. "R: A language and environment for statistical computing." Accessed 23 January 2014 at http://www. R-project.org/.

Randolph, K. 2009. Crown Condition. In: Ambrose, M.J and B.L. Conkling, eds. 2009. Forest health monitoring: 2006 national technical report. Gen. Tech. Rep. SRS-117. Asheville, NC: U.S. Department of Agriculture, Forest Service, Southern Research Station. 118 pp.

Randolph, K., W.A. Bechtold, R.S. Morin and S.J. Zarnoch. 2009. From detection monitoring to evaluation monitoring-a case study involving crown dieback in northern white-cedar. In: McWilliams, W., G. Moisen, R. Czaplewski, comps. 2009. Forest Inventory and Analysis (FIA) Symposium, October 21-23, 2008. Park City, UT. Proc. RMRS-P-56CD. Fort Collins, CO: U.S. Department of Agriculture, Forest Service, Rocky Mountain Research Station. [CDROM].

Schomaker, M.E., S.J. Zarnoch, W.A. Bechtold, D.J. Latelle, W.G. Burkman and S.M. Cox. 2007. Crown-condition classification: a guide to data collection and analysis. Gen. Tech. Rep. SRS-102. Asheville, NC: U.S. Department of Agriculture, Forest Service, Southern Research Station. 78 pp.

Smith, W.B., P.D. Miles, C.H. Perry and S.A. Pugh. 2009. Forest resources of the United States, 2007. Gen. Tech. Rep. WO-78. Washington, DC: Department of Agriculture, Forest Service, Washington Office. 336 pp.

Spetich, M.A. and H.S. He. 2008. Oak decline in the Boston Mountains, Arkansas, USA: spatial and temporal patterns under two fire regimes. Forest Ecol. Manage. 254: 454-462.

Steinberg, D. and P. Colla. 1997. CART-Classification and regression trees. San Diego: Salford Systems.

Suarez, M.L., L. Ghermandi, and T. Kitzberger. 2004. Factors predisposing episodic drought-induced tree mortality in Nothofagussite, climate sensitivity and growth trends. J. Ecol. 92: 954-966.

Tainter, F.H., W.A. Retzlaff, D.A. Starkey and S.W. Oak. 1990. Decline of radial growth in red oaks is associated with short-term changes in climate. Eur. J. Forest Pathol. 20: 95-102.

Therneau, T.M., B. Atkinson and B. Ripley. 2012. "Package 'rpart." Accessed 23 January 2014 at: http://cran.r-project.org/web/packages/rpart/rpart.pdf.

Voelker, S.L., R.M. Muzika, and R.P. Guyette. 2008. Individual tree and stand level influences on the growth, vigor, and decline of red oaks in the Ozarks. Forest Sci. 54(1): 8-20.

Wilhite, D.A. 2000. Drought as a natural hazard: concepts and definitions. In: Wilhite, D.A., editor. Drought: A Global Assessment. Routledge, London, UK. 752 p.

Williams, A.P., C.D. Allen, C.I. Millar, T.W. Swetnam, J. Michaelsen, C.J. Still, and S.W. Leavitt. 2010. Forest responses to increasing aridity and warmth in the southwestern United States. Proceedings of the National Academy of Science 107(50): 21289-21294.

Zwieniecki, M.A., C.K. Boyce, and N.M. Holbrook. 2004. Hydraulic limitations imposed by crown placement determine final size and shape of Quercus rubra L. leaves. Plant Cell Environ. 27: 357-365. 